\title{
An analysis of the Visual Representation of Redox Reactions and Related Content in Brazilian Secondary School Chemistry Textbooks
}

\author{
Luciane Fernandes Goes ${ }^{1 *}$, Xiaoge Chen ${ }^{2}$, Keysy Solange Costa Nogueira ${ }^{3}$, Carmen Fernandez ${ }^{1}$, and Ingo Eilks ${ }^{2}$ \\ ${ }^{1}$ Institute of Chemistry, University of São Paulo, São Paulo, Brazil, ${ }^{2}$ Department of Biology and Chemistry, Institute for Science Education, University \\ of Bremen, Bremen, Germany, ${ }^{3}$ Federal University of Santa Catarina, Blumenau, Santa Catarina, Brazil
}

*Corresponding Author: luciane.goes@usp.br

\section{ABSTRACT}

The objective of this study was to analyze visual representations of redox reactions and related content in four Brazilian secondary school chemistry textbooks. The study aimed to identify which representations were used and to evaluate how these representations were linked to one another and to the main text. Data were analyzed regarding representational levels and the degree of relatedness between the different levels and the main text. Further analysis focused on the intended function of images and which curriculum orientation they indicated. The sample was comprised of 286 visual representations. The results showed that most of the visual representations merely served a decorative function and were not explicitly used to further understanding of the content in the main text. The findings indicated that the textbooks in this sample prioritized two separate levels of representation: The macroscopic and the symbolic. Only a few submicroscopic and multilevel representations could be found. The textbook illustrations indicated a strong "structure of the discipline" orientation of the curriculum, which was illustrated with orientations taken from everyday life, technology, and industry. It emphasizes the importance of using illustrations in textbooks, because of its influence on the construction of concepts, in particular the concept of redox reactions. Based on this research, it is possible for chemistry teachers to observe the limitation of these materials and carefully select the textbook used in their curricula. Moreover, the results can contribute to improving the quality of textbooks.

KEY WORDS: chemistry textbook; levels of representation; redox reactions; textbooks analysis; visual representation

\section{INTRODUCTION}

$\mathbf{R}$ edox reactions are a type of chemical reaction involving the gain and loss of electrons by electron transfer between different chemical species. This type of reaction is essential for many basic life functions such as respiration and photosynthesis. It is also the basis for many everyday processes found in batteries, breathalyzer test, electroplating, corrosion, and the oxidation of fruits and vegetables (Österlund et al., 2010). Redox reactions are one of the central concepts of chemistry taught at the secondary school level in several countries (AduGyamfi et al., 2018; Basheer et al., 2017; De Jong et al., 1995). However, redox reactions are commonly perceived to be one of the most difficult topics to teach and to learn (De Jong and Treagust, 2002). Furthermore, it is one of the content areas in chemistry that allows for the inclusion of socioscientific questions. Examples include reflection on the importance of conscious consumption and discard of batteries, the production of metals such as aluminum, and/or the protection of metals against corrosion. It is possible to establish the relationship between science, technology, and society. This approach has great potential for developing students' skills (Eilks, 2015).

One of the important aspects of an advanced understanding of redox reactions is dealing with their three representational levels: The macroscopic, submicroscopic, and symbolic levels (Johnstone, 1991). Macroscopically, students are required to observe, for example, changes in color, the formation of precipitates, or gases released during a reaction. At the same time, students are expected to understand electron movements to describe the submicroscopic, particulate level. At the symbolic level, students must be able to represent reactions by writing redox equations. In general, it is difficult to establish direct relationships between these three representational levels of chemistry (Eilks et al., 2007; Tan et al., 2009). Unfortunately, students tend to most frequently explain phenomena at the macroscopic level, because they live in the macroscopic world and can only make observations at this level (Gabel, 1999).

It is essential for teachers to know how to explain redox reactions, how to connect the different representations of corresponding phenomena, and how to use different representations of the content (Valanides et al., 2003). However, studies have revealed that even teachers sometimes have difficulties in explicitly connecting the representational levels. They either move between them without explanation or, just like their students, tend to prioritize the macroscopic level (Gabel, 1999). A study on experienced teachers in Germany showed that even though teachers might know different 
approaches to teaching submicroscopic concepts, these concepts are often poorly elaborated in teachers' understanding and teachers are reluctant to change their teaching practices (Eilks, 2013).

Visual representations can help in reducing student difficulties when moving between the different representational levels (Gilbert, 2006) if pupils know how to interpret them (Pintó and Ametller, 2002). It has also been suggested that visual representations have the potential to contribute to a better understanding of the meaning of texts in textbooks (Dimopoulos et al., 2003). Research reports that when learners have access to visual representations in addition to a text, it becomes easier for them to comprehend the concepts presented (Carney and Levin, 2002; Tan et al., 2009). Since much of the contact by the students with the visual representation of content is mediated through textbooks (Lee, 2010), it is important to ensure that visual representations are carefully used in textbooks. It has been noted that the mere presence of images in textbooks does not guarantee that it will facilitate the understanding of contents (Gkitzia et al., 2011), coherence between the text and the images is necessary. Furthermore, identifying the purpose of images in the textbook can help the teacher to use them critically.

Although there are several studies that investigated the role of images in textbooks (Gkitzia et al., 2011; Izquierdo and Gouvea, 2008; Khaddoor et al., 2017; Llanos and Otero, 2018; Nyachwaya and Wood, 2014), further analyses may be carried out for different topics and educational environments, to compare and contrast how representations are used in chemistry textbooks in the foreground of an international context (Kapici and Savasci-Açikalin, 2015). The research interest of the current study was: How is content related to redox reactions visually represented in Brazilian chemistry textbooks? The purpose of the study was not to indicate eventual conceptual errors in the textbooks, but rather to characterize how the textbook authors adapted visual representations related to redox reaction content.

\section{THEORETICAL FRAMEWORK}

Textbooks have an important place in education, mainly as a resource for teachers and students (Devetak and Vogrinc, 2013). Many teachers depend on the textbook to guide their teaching efforts (Stern and Roseman, 2004). They use them to select the subject matter, establish a teaching sequence, choose exercises, and teach specific topics and activities (Bizzo et al., 2012). Students interact with textbooks at school, use them to study at home, and sometimes list them as references for advanced papers or projects (Gkitzia et al., 2011). Textbooks regularly represent commonly used practices in the curriculum, since experienced in-service teachers frequently write them. They are affected by authors' styles as they transmit their views on the national curriculum. In this sense, textbooks direct the orientation of the curriculum (Roseman et al., 2010;
Khaddoor et al., 2017) and provide guidance about pedagogical approaches (Souza and Porto, 2012).

Research reports those conceptual difficulties, alternative conceptions, and even the use of inappropriate language and misleading visual representations in textbooks occur (Schmidt et al., 2007; Barke et al., 2009; Österlund et al., 2010). Besides that, inadequate images in textbook can be didactical obstacles of learning (Carvalho and Clément, 2007). A study on how future chemistry teachers understand electrochemistry concepts such as cell potential and galvanic cell equilibrium attributed one learning difficulty "to the insufficient explanation of the relevant concepts in textbooks" (Özkaya, 2002. p. 738).

Considering the importance of textbooks and realizing that the representations found in them influence teachers' teaching and students' learning (Pozzer-Ardenghi and Roth, 2005), the current study analyzed the types of representations in Brazilian chemistry textbooks on the concept of redox reactions. While the content of redox reactions can be treated as pure chemistry; it can also be presented within everyday life situations, environmental questions, and technology applications (Eilks et al., 2013). In the literature on chemistry teaching, the research on redox processes can be divided into categories:

- Teaching strategies and practical activities involving redox and/or electrochemical processes (Huddle et al., 2000; Niaz and Chacón, 2003; Sesen and Tarhan, 2013)

- Teaching and learning of redox and/or electrochemical processes with a focus on students, including works on alternative conceptions (Garnett and Treagust, 1992a; 1992b; Barral et al., 1992; Ringnes, 1995; Posada, 1997; Sanger and Greenbowe, 1997a; 1997b; 2000; De Jong and Treagust, 2002; Niaz and Chacón, 2003; Schmidt et al., 2007; Lee, 2007; Barke et al., 2009; Österlund and Ekborg, 2009)

- Teaching and learning of redox and/or electrochemical processes with a focus on teachers (De Jong et al., 1995; Özkaya, 2002; De Jong and Treagust, 2002)

- Processes and/or electrochemistry in chemistry textbooks (Sanger and Greenbowe, 1999; Mendonça et al., 2004; Österlund et al., 2010)

A fundamental aspect about the teaching of redox processes that lead to alternative conceptions is the coexistence of several explanatory models, which sometimes is confused by students, teachers, and even authors of textbooks (Österlund et al., 2010). In addition, many students are unable to differentiate reactions at the macroscopic level of substances and at the submicroscopic level of particles (Barke et al., 2009).

The idea of the different types of representations of chemistry generally refers back to the works of Johnstone from the 1980s onward. Johnstone had already proposed a triple relationship between the different representational levels of chemistry as early as 1982. For him, chemistry exists at least at three levels: (a) Descriptive and functional, where is possible to 
see, handle and describe materials and their properties; (b) representational, in which formulas and reaction equations represent chemical substances processes; and (c) explanatory, which concerns the atomic and molecular level (Johnstone, 1982). Later, Johnstone strengthened his discussion about the triple relationship and referred to it in various ways. In 1991, Johnstone arranged the three levels as the vertices of a triangle ("triangle of levels of thought") and renamed them the macro, submicro, and symbolic levels (Johnstone, 1991). For Johnstone, no level is superior, each merely complements the others. In 1993, Johnstone emphasized this in his model by naming the components, "the macrochemistry of the tangible, edible, visible; the submicrochemistry of molecular, atomic, and kinetic; and the representational chemistry of symbols, stoichiometry, and mathematics" (Johnstone, 1993. p. 702). In 2006, he explained the possible overlapping of the three levels. The vertices of the triangle (Figure 1) were considered "the three conceptual levels of chemistry" (Johnstone, 2006. p. 59). In 2010, he presented the triangle as "three aspects of representation in the physical sciences" (Johnstone, 2010. p. 24). The vertices were called macro-tangible; molecularinvisible; and symbolic-mathematical.

In his articles, Johnstone worried about the use of the three levels at the same time. For him, a chemist may be able to move between the sides of the triangle and into the triangle, but students do not easily understand this. Becoming familiar with the movement between the edges of the triangle was considered by Johnstone to be a slow process. He, therefore, suggested that chemistry "concepts must be built from the macroscopic and gradually be enriched with submicroscopic and representational aspects" (Johnstone, 2010. p. 28).

Despite different interpretations, varying representations, and distinct terminologies (Gilbert and Treagust, 2009), Johnstone's model is still used by many researchers in chemistry education (Treagust et al., 2003; Eilks et al., 2007; Al-Balushi and Al-Harthy, 2015; Becker et al., 2015; Irby et al., 2016). For this study, we decided to start our investigation from using the chemistry triangle as initially proposed by Johnstone (1991). Johnstone (2010) noted, "any additions to it are superfluous and complicating. There is no hierarchy implied in this model, and any additions to it are superfluous and complicating. Let us keep things simple or the model

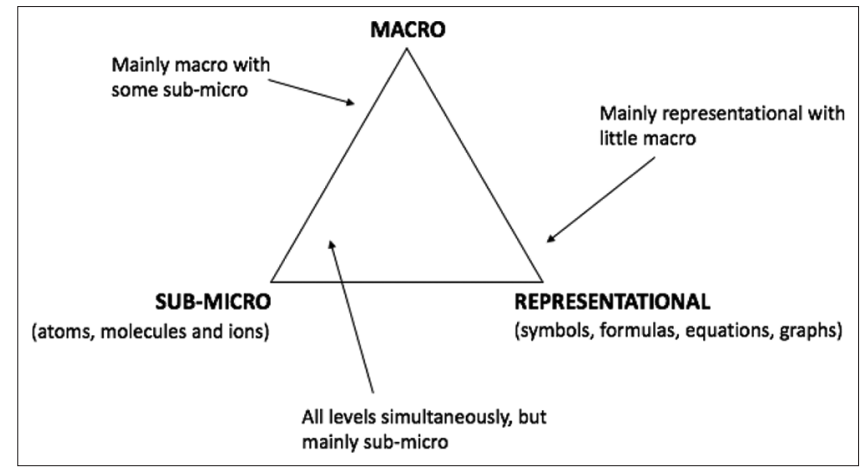

Figure 1: The three conceptual levels of chemistry (Johnstone, 2006) will not be used. However, further interpretations such as those by Mahaffy (2004) and Sjöström and Talanquer (2014) did play a role in our interpretation of visual representations in the textbooks. This occurred as we looked for curriculum orientations as suggested by Eilks et al. (2013) and as it is indicated by the use of corresponding illustrations connected to the three representational levels. This interpretation is near to Mahaffy (2004) as he suggested to add a dimension of context to the triangle.

In addition to the different levels of representation, it is important to analyze the functions of the images. Visual representations can be classified as decorative, representational, organizational, or interpretational (Slough et al., 2010; Carney and Levin, 2002). Decorative images are one of the most prevalent functions of representations (Perales and Jimenez, 2002; Cook, 2006; Gibin et al., 2009; Nyachwaya and Gillaspie, 2016). Similarly, it can be said that the relatedness of the images to text is a complementary function as it describes the image verbally and helps the readers to understand what the image is about. Gkitzia et al. (2011) found that more than half of the representations are generally related to the corresponding concepts.

There is already research dedicated to studying issues related to the different levels of representations used in the sciences and their teaching, related to visual representations in general (Cook, 2006; Eilks et al., 2012), and in textbooks in particular (Cheng and Gilbert, 2014; Kapici and Savasci-Açikalin, 2015). There is, however, very limited information available about the visual representation of redox reaction content in chemistry textbooks. Sanger and Greenbowe (2000), Mendonça et al. (2004), and Österlund et al. (2010) analyzed the content and teaching models related to the redox and/or electrochemical processes. However, only one of these studies had a focus on the Brazilian educational context and this focused on the field of organic chemistry (Mendonça et al., 2004).

Thinking about the difficulties reported in literature about redox reactions content, and considering the hypothesis that a significant part of the difficulties of the students can be derived from the adoption of inappropriate language and misleading illustrations, this study chose to describe the kinds of visual representations regarding the macroscopic, submicroscopic, and symbolic levels used in Brazilian chemistry textbooks for redox reactions. Furthermore, the study explored how these representations were linked one to another, how they were related to the main text, and which curriculum orientations were indicated by the visual representations.

This study was guided by the following research questions: (1) What is the level of chemistry that chemical representations in the chapter about redox reactions of Brazilian secondary school chemistry textbooks emphasize? (2) How are the representations levels linked to each other? (3) What is the degree of relatedness between chemical representations in the chapter about redox reactions and text content? (4) What function do representations in the chapter about redox reactions 
serve in the textbooks? (5) Which curriculum orientation is indicated by visual representations in the textbooks?

\section{BACKGROUND AND METHODOLOGY OF THE STUDY}

At present, most of Brazilian public schools receive textbooks approved by the National Textbook Program (PNLD Programa Nacional do Livro Didático), a program of the Brazilian federal government (Brasil, 2009). In the year 2015, for example, the National Fund for Educational Development, through the National Textbook Program (PNLD), benefited more than 30 million students and more than 140 million copies were distributed among 123, 000 schools, totaling almost BRL 200 million (approximately USD 55 million) distributed among the publishers (FNDE, 2017). This support the argument that the official curriculum documents suggest the programmatic content in textbooks and that the various authors write textbooks in accordance with the national curriculum.

Given the wide access of students and teachers to the textbooks, as well as their supposed use in school institutions for 3 years of the high school, it seems reasonable to analyze the collections approved. Each collection consists of three textbooks (three volumes) and each volume is intended for 1 year of high school. For this study, we focused only on the secondary chemistry textbooks that were approved by the National Textbook Program (PNLD) in 2015 and were currently being use in schools in Brazil.

The textbooks collection was analyzed for any images in chapters dealing explicitly with redox reactions. Two different researchers analyzed the images independently. The four textbooks chosen were the volumes in each collection that address redox (Table 1).

Except for the first textbook (TB1), all of the other textbooks deal with redox reactions mostly in the second volume, which is generally meant to be used in the $2^{\text {nd }}$ year of high school. The fact that the redox content is concentrated in volume two for three textbooks collection is in accordance with the National Curricular Parameters for High School $(\mathrm{PCN}+)$ in Brazil (Brasil, 1999).

The sample contained 286 visual representations. This sample included all the visual representations in the related chapters even though some of them implicitly related to the

\begin{tabular}{ll}
\hline Table 1: & Chemistry textbooks analyzed in this paper \\
\hline Textbook & Reference \\
\hline TB1 & $\begin{array}{l}\text { Santos and Mól (2013). Química Cidadã 3 (Citizen } \\
\text { Chemistry 3) (2nd ed.). AJS Ltda }\end{array}$ \\
TB2 & $\begin{array}{l}\text { Mortimer and Machado (2013). Química 2: ensino médio } \\
\text { (Chemistry 2: High School) (2nd ed.). Scipione }\end{array}$ \\
TB3 & $\begin{array}{l}\text { Fonseca (2013). Química 2 (Chemistry 2) (1st ed.). Ática } \\
\text { TB4 }\end{array}$ \\
& $\begin{array}{l}\text { Antunes (2013). Ser Protagonista: Química 2 (Be } \\
\text { protagonist: Chemistry 2) (2nd ed.). Edições SM. }\end{array}$ \\
\hline
\end{tabular}

concept of redox reactions. These 286 visual representations were analyzed using five different categories: Level of representation, degree of correlation between representations comprising two or more levels, relatedness to text, function of images, and indications for the orientation of the curriculum. The first three categories above were based on the criteria for the evaluation of chemical representations given by Gkitzia et al. (2011). One of the purposes of this research was to analyze what kinds of representations were present in each textbook and how they were used. Therefore, we decided to classify each representation when it appeared alone or in combination with another level of representation. We also analyzed how the images and texts are related to one another, based on three out of the six typologies initially proposed by Gkitzia et al. (2011): completely related, partially related, and unrelated. The categories and subcategories, as well as their descriptions, are shown in Table 2.

Regarding the function of images, we chose Carney and Levin's (2002) three categories that had been used in several works related to the analysis of visual representations in textbooks (Slough et al., 2010; Nyachwaya and Gillaspie, 2016). Carney and Levin (2002) suggested four common functions for images: Decorational, representational, organizational, and interpretational. The functionality of the illustrations was difficult to evaluate, so we could only consider three categories of illustrations. After analysis, the decorational and representational categories were grouped, because the findings appeared to be very similar to one other. In these two categories, the visual representations function to illustrate or exemplify the content that is already in the text. Furthermore, a lack of illustration for these categories would not negatively influence the conceptual understanding of the text. The three categories are described in Table 3.

As has already been mentioned above, textbooks also represent orientations of the curriculum (Roseman et al., 2010). The accompanying visual resources can indicate such orientations, for example, by referring to the everyday life relevance of chemistry, its historical development or chemistry's industrial ramifications. To dig into this question, the illustrations were analyzed using the list of potential curriculum orientations summarized in Eilks et al. (2013) (Table 4).

\section{FINDINGS AND DISCUSSION}

In this study, we found 286 visual representations in the chapters related to redox reaction content. In general, the same levels of representation appeared throughout the four chemistry textbook series. Figure 2 presents the percentage of visual representations in each textbook for each representational level category.

None of the four textbooks covered all of the seven representational levels as given in Table 2. Macroscopic representations were the most common type identified (77\%) followed by combinations of the macroscopic and symbolic levels $(18 \%)$. These results are in line with the results by 


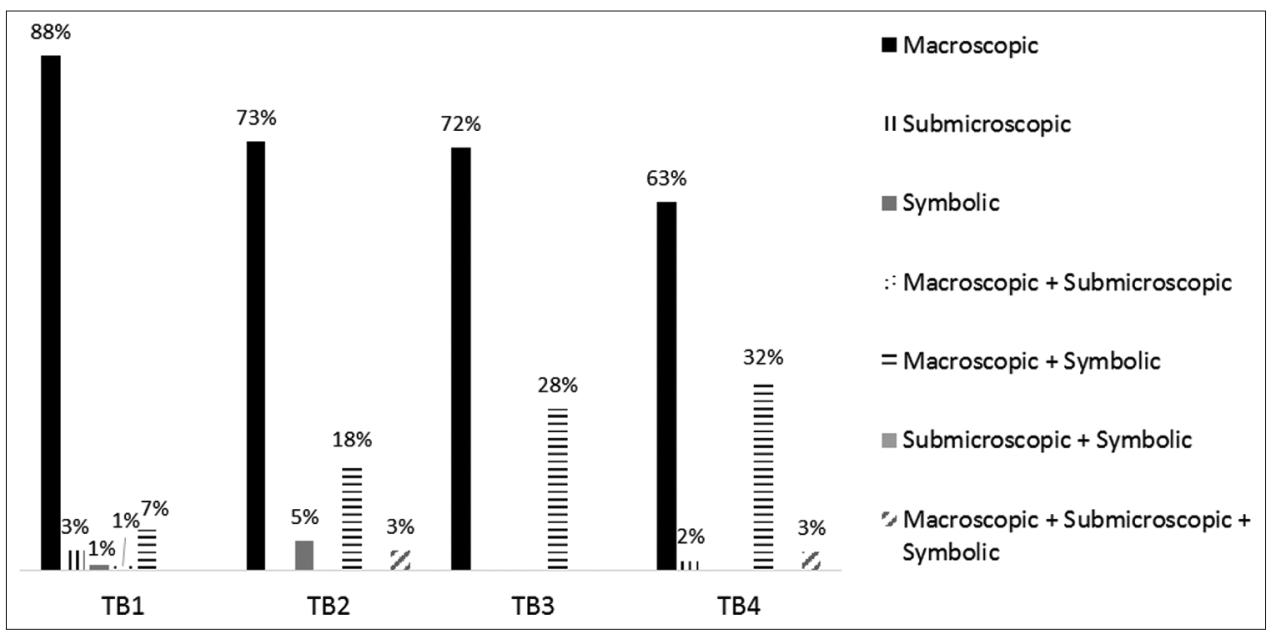

Figure 2: Distribution of visual representations regarding representational levels in four Brazilian textbooks (TB)

Table 2: Definition of analytical categories (adapted from Gkitzia et al., 2011)

\begin{tabular}{|c|c|c|c|}
\hline \multicolumn{3}{|l|}{ Category } & Subcategory \\
\hline \multirow{7}{*}{\multicolumn{3}{|c|}{ Levels of representation }} & Macroscopic \\
\hline & & & Submicroscopic \\
\hline & & & Symbolic \\
\hline & & & Macro and submicroscopic \\
\hline & & & Macroscopic and symbolic \\
\hline & & & Submicroscopic and symbo \\
\hline & & & $\begin{array}{l}\text { Macroscopic, submicroscop } \\
\text { and symbolic }\end{array}$ \\
\hline \multirow{3}{*}{\multicolumn{3}{|c|}{$\begin{array}{l}\text { Degree of correlation between representations } \\
\text { comprising two or more levels }\end{array}$}} & Sufficiently linked \\
\hline & & & Insufficiently linked \\
\hline & & & Unlinked \\
\hline \multirow{3}{*}{\multicolumn{3}{|c|}{ Relatedness to text }} & Completely related \\
\hline & & & Partially related \\
\hline & & & Unrelated \\
\hline \multicolumn{4}{|c|}{$\begin{array}{l}\text { Table 3: Definition of image functions by category } \\
\text { (adapted from Carney and Levin, 2002) }\end{array}$} \\
\hline Category & Subcategory & \multicolumn{2}{|l|}{ Description } \\
\hline \multirow[t]{3}{*}{$\begin{array}{l}\text { Function of } \\
\text { images }\end{array}$} & Decorative & \multicolumn{2}{|c|}{$\begin{array}{l}\text { Not relevant to the text-illustrations } \\
\text { can help the reader enjoy the textbook } \\
\text { by making it more attractive. }\end{array}$} \\
\hline & Organizational & \multicolumn{2}{|c|}{$\begin{array}{l}\text { Illustrations can help the reader } \\
\text { organize information into a coherent } \\
\text { structure and encourage more detailed } \\
\text { processing of text }\end{array}$} \\
\hline & Interpretational & \multicolumn{2}{|c|}{$\begin{array}{l}\text { Strong relationship to the content - } \\
\text { illustrations can explain and help the } \\
\text { reader better understand concepts and } \\
\text { ideas in the text. }\end{array}$} \\
\hline
\end{tabular}

Chen et al. (2019) in the case of chemistry textbooks from the People's Republic of China. More than half of the images used illustrations that address only the macroscopic level. The images in the Chinese textbooks have different

Description

Presents only observable and realistic aspects

Illustrates unobservable and abstract aspects

Uses symbols and codes of chemistry

Represents two levels: Macroscopic and submicroscopic

Represents two levels: Macroscopic and submicroscopic

Represents two levels: Submicroscopic and symbolic

Represents all three levels: Macroscopic, submicroscopic, and symbolic

Equivalence of the surface features of the components is clearly indicated

Equivalence of only some surface features is indicated clearly

Subordinate representations are just placed next to one another; there is no indication of the equivalence of their surface features

Representation depicts the exact text content

Representation depicts a similar subject to the text but not the exact one

Representation is irrelevant to the text content; text describes the contents without mentioning the correspondence to the representation

Table 4: Evidence of a curriculum orientation (inspired by Eilks et al., 2013)

\begin{tabular}{lll}
\hline Category & Subcategory & Description \\
\hline $\begin{array}{l}\text { Curriculum } \\
\text { orientation }\end{array}$ & $\begin{array}{l}\text { Structure of the } \\
\text { discipline orientation }\end{array}$ & $\begin{array}{l}\text { Illustrations represent scientific } \\
\text { theories and facts and their relation } \\
\text { to one another }\end{array}$ \\
& $\begin{array}{l}\text { History of science } \\
\text { orientation }\end{array}$ & $\begin{array}{l}\text { Illustrations represent scientific } \\
\text { content as it emerged in the past or } \\
\text { its historical development }\end{array}$ \\
& $\begin{array}{l}\text { Everyday life } \\
\text { orientation } \\
\text { Environmental } \\
\text { orientation }\end{array}$ & $\begin{array}{l}\text { Illustrations represent questions } \\
\text { from everyday life } \\
\text { content behind questions of } \\
\text { environmental protection }\end{array}$ \\
& $\begin{array}{l}\text { Industry and } \\
\text { technology } \\
\text { orientation } \\
\text { Socioscientific issues } \\
\text { technology, industry, and their } \\
\text { arientation }\end{array}$ & $\begin{array}{l}\text { Illustrations represent situations } \\
\text { that provoke the students to think } \\
\text { about societal questions }\end{array}$ \\
\hline
\end{tabular}


functions such as exemplification and contextualization. One example is a picture made up of various objects, some electronic, some not, which are fully or partially made of metal (Figure 3 image a). These representations alone, however, do not help the understanding of the other representational levels in chemistry. Learning at only one level can lead to fragmented knowledge since students do not know how the same phenomenon can be represented and related at the other levels (Treagust et al., 2003).

Representations at the submicroscopic level primarily appear whenever illustrations portray two or more levels simultaneously. Images classified solely as submicroscopic are present in only two of the textbooks. They represent $<2 \%$ of the illustrations. For example, Figure 3 image b presents a model explaining metallic bonds, in which it shows solid metal as being constituted of atoms with positive charges (big spheres), surrounded by free electrons (small dots). TB3 never addressed the submicroscopic level visually, even though this level of representation is fundamental in chemistry.

Submicroscopic illustrations represent unobservable aspects, thereby propitiating the understanding of the behavior of ions, atoms, and molecules. Due to the invisible and non-tactile nature of the particle level, didactic approaches generally suggest the thorough use of images and other forms of visual illustrations at the submicroscopic level for effective learning. Ideally, they should also be associated with the other levels (De Jong et al., 2013).

Illustrations showing only the symbolic level appear in two textbooks. The second most frequent form of representation combined the symbolic level with the macroscopic level. The symbolic level is essential for learning the language of chemistry, which is formed by specific symbols and codes. It cannot be left out of the learning of chemistry (Markic et al., 2013). These symbols and codes are also used to represent macroscopic and submicroscopic entities (Gilbert and Treagust, 2009). For example, Figure 3 image c shows a representation of copper-zinc galvanic cell at the macroscopic level and also describes the specific chemical reaction on the symbolic level.

Only two textbooks contain images combining all three representational levels. This represents $<2 \%$ of the total illustrations. Images linking different levels together can be useful tools in the learning process because they establish a relationship between theory and practice (Gibin and Ferreira, 2013). Out of 286 illustrations total, only 57 represent two or three levels simultaneously. These illustrations were analyzed to find the degree of correlation between the different levels. Figure 4 suggests that the selected textbooks present most of their multiple representations in an insufficiently linked manner. This result differs to findings reported Chen et al. (2019) for the case of Chinese chemistry textbooks. In the case of textbooks from different Chinese communities, most representations with two or three levels were sufficiently linked. The different representations in the Chinese textbooks were connected by arrows and/or lines.

Only two of the textbooks had representations which were sufficiently linked. More than $50 \%$ of all the multiple representations have an insufficient correlation between different levels. Roughly $30 \%$ of the illustrations do not indicate any relationships at all. This type of representation has arrows to indicate the correlation between different levels.

For example, Figure 5 image A shows an insufficiently linked representation, because the macroscopic and the symbolic images are placed in parallel. Students may understand the equivalence (Gkitzia et al., 2011), but it is not clearly indicated that the element symbols are both the electrodes and the formula for the aqueous solutions of the corresponding substances. Figure 5 image $\mathrm{B}$ is an unlinked representation since the macroscopic and the symbolic representation are merely placed next to one another. There is no indication where the reactions occur or what the relationship between these two levels is. Generally, the textbooks did not explain the correlation between the different levels of representation. This can be a hindering factor if students are supposed to learn how to move between and understand the different types of representations.

Relating images with the text is necessary because graphics alone cannot express the intended meaning in most cases. Images unrelated to the text can also cause misconceptions (Gibin et al., 2009). Representations should be accompanied by well-planned explanations that support students' understanding of the concept shown in the image. The meaning of certain images may be quite obvious for teachers. However, this is often the pupils' first contact with such representations. A lack of easily understood information may hinder their correct understanding of the concept (Gibin et al., 2009). Figure 6 shows that the textbooks present the majority of images as
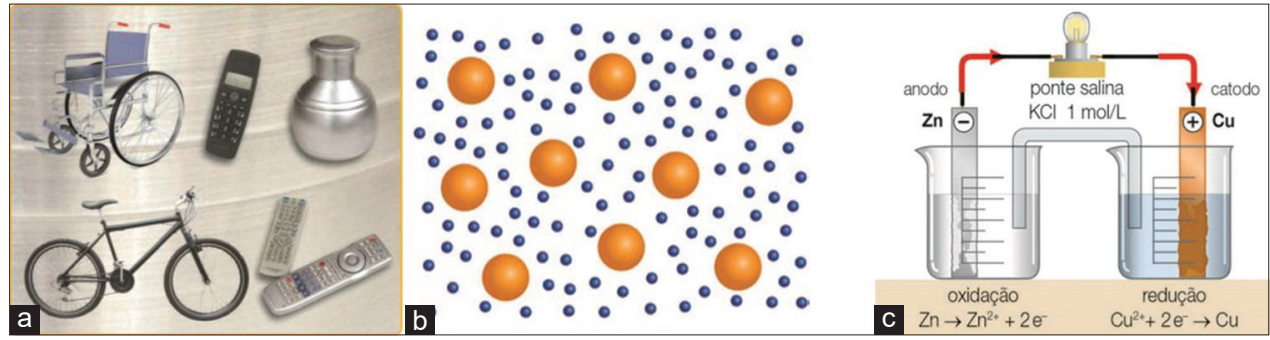

Figure 3: Examples of visual representations regarding the categories (a) macroscopic level, (b) submicroscopic level, (c) macroscopic and symbolic level. Santos and Mól (2013). Química Cidadã (2ed. Vol.3). São Paulo: AJS Ltda. Reproduced by permission of AJS Ltda, São Paulo, São Paulo 


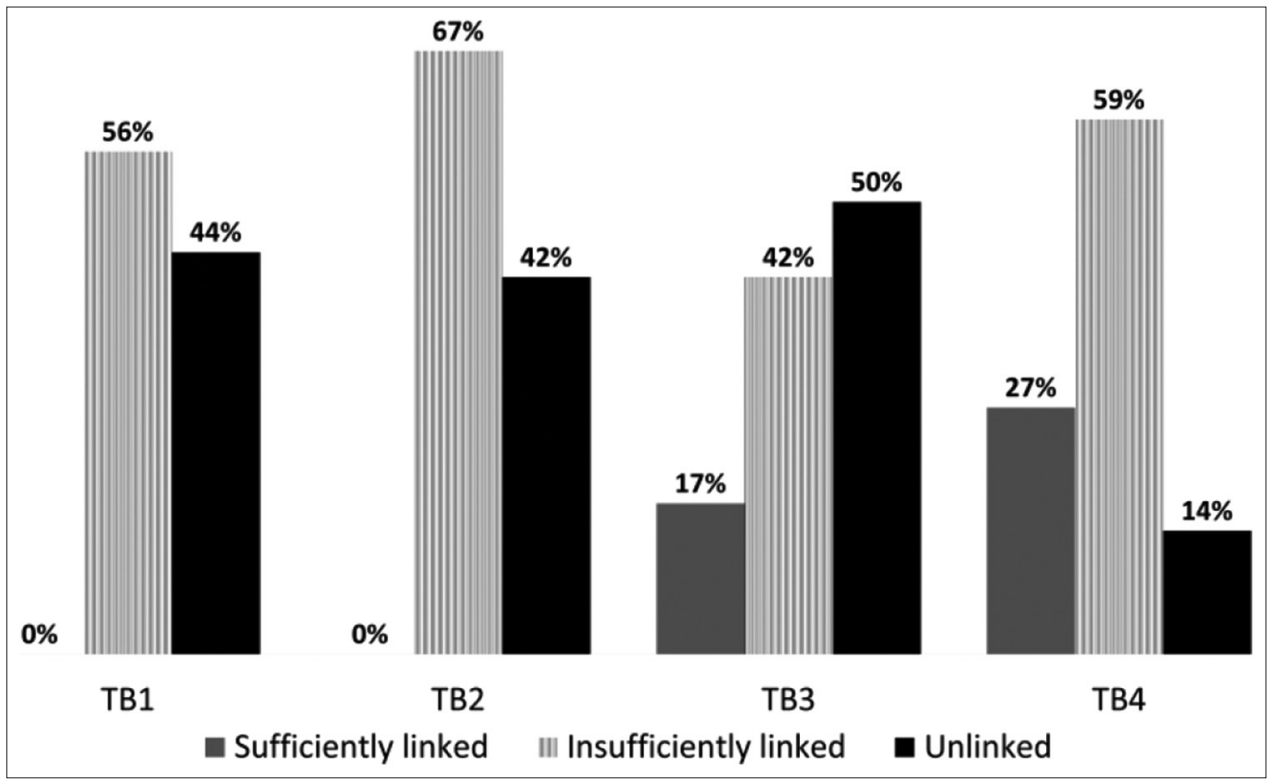

Figure 4: Distribution of visual representations regarding the degree of correlation between representations comprising two or more levels in four Brazilian textbooks (TB)

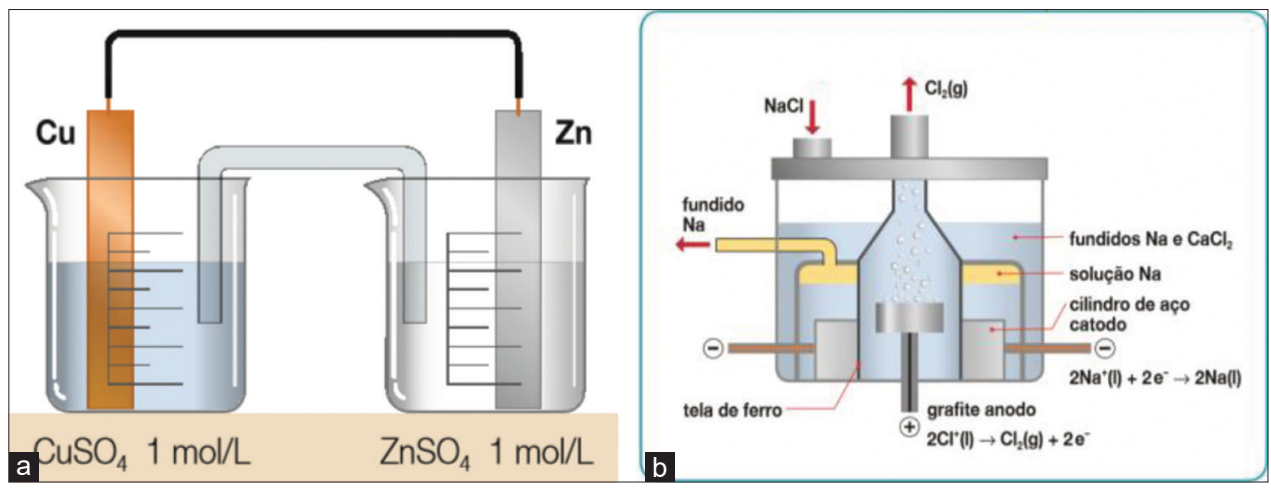

Figure 5: Examples of visual representations regarding the categories (a) insufficiently linked representation, (b) unlinked representation. Santos and Mól (2013). Química Cidadã (2ed. Vol.3). São Paulo: AJS Ltda. Reproduced by permission of AJS Ltda, São Paulo, São Paulo

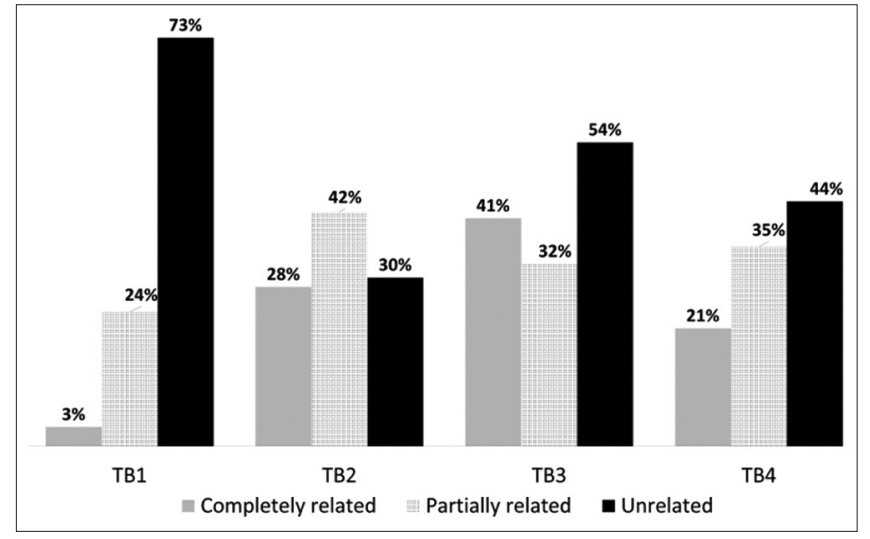

Figure 6: Distribution of visual representations and their relatedness to the text in four Brazilian textbooks (TB)

unrelated to the text. The only exception was TB2. The rest of the books did not establish clear and explicit correspondences between the images provided and the subject matter directly addressed in the texts.
More than half of the total representations (52\%) were unrelated to the texts, and $30 \%$ were only partially related. Only $17 \%$ of the images were completely and explicitly related. This lack of relationship between text and images can contribute to a lack of understanding among students. TB3 is somewhat differently structured and has about $41 \%$ of its images completely related to the relevant texts. This connectedness helps students to understand the material presented in the text offerings. This is another category of analysis that differs from Chinese chemistry textbooks, in which more than $75 \%$ of the representations were completely related to the text (Chen et al., 2019). This category is related to the category of function of images (Figure 7). From the result, it is more evident that one of the main functions of the representations was just to get readers' attention. The decorative function dominates, with more than $55 \%$ of the images serving a decorative purpose.

An example of such an illustration is given in Figure 8 image A. It shows different battery types, it assumes that students know what standard batteries look like. Figure 8 image B is an 
example of the organizational function of visual representation. It sketches the setup of a hydrogen electrode, which has been detailed in the text. This kind of image can help students to organize textual information and connect it visually in their imagination. Figure 8 image $\mathrm{C}$ focuses even more completely on function. It intends to help students to picture better textual information about the processes occurring within a Daniell element (a voltaic cell). The illustration tries to illustrate the flow of electrons and ions with the help of arrows. It must,

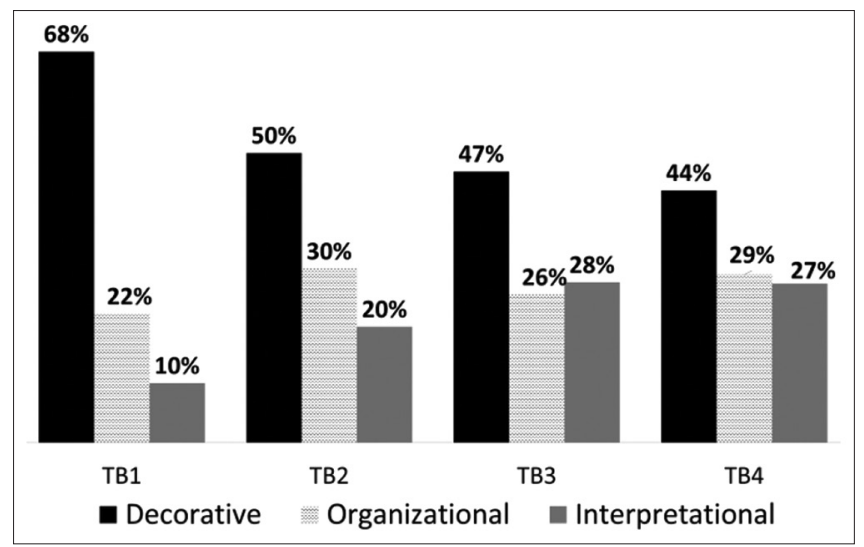

Figure 7: Distribution of the visual representations regarding to function of images on four Brazilian textbooks (TB) however, be said that the graphic is a problematic construct. Neither the zinc nor the copper electrode is composed of atoms and, thus, cannot change in the fashion in which this figure presents them (Eilks et al., 2012). A solid zinc electrode seems to produce round zinc ions when it loses electrons magically. Round copper ions seem to disappear as they absorb electrons, become copper atoms, and attach themselves to the solid copper electrode. This seeming sleight-of-hand often confuses students, especially if they already know about the Law of the Conservation of Mass.

We found that (except TB1) about half of the total illustrations in the textbooks represent scientific theories or facts (Figure 9).

This indicates evidence for a structure of the discipline approach. In that case, we should see more submicroscopic and multilevel representations accompanying the written material. This is unfortunately not the case. Similar to the study of Izquierdo and Gouvea (2008), the analysis of images indicates that textbooks present science as a theoretical point of view on everyday life. Figure 10 image A gives an example of one such figure. It shows a lab experiment which involves placing a piece of copper in a solution of silver nitrate. The other half of the illustration, however, approaches redox content in a contextualized way. It tried to involve the students with issues related to everyday life or technology and industry. This

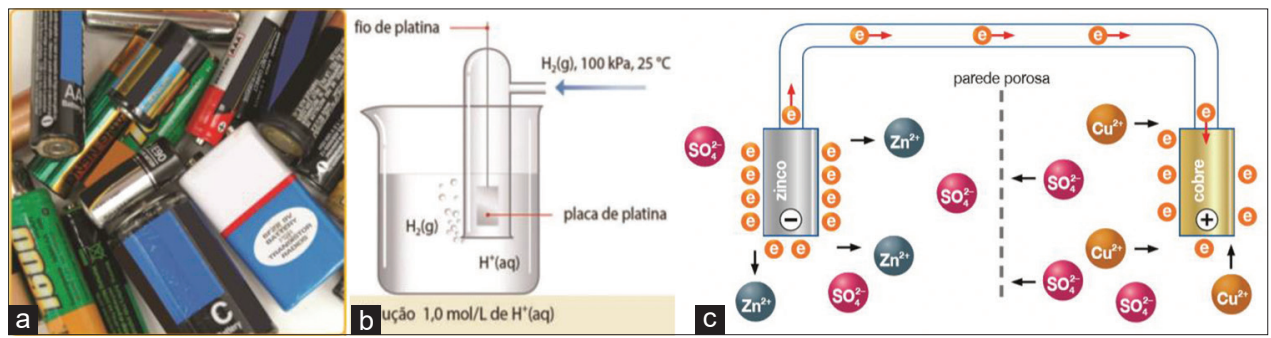

Figure 8: Examples of visual representations of (a) decorative function, (b) organizational function, (c) interpretational function. Santos and Mól (2013). Química Cidadã (2ed. Vol.3). São Paulo: AJS Ltda. Reproduced by permission of AJS Ltda, São Paulo, São Paulo

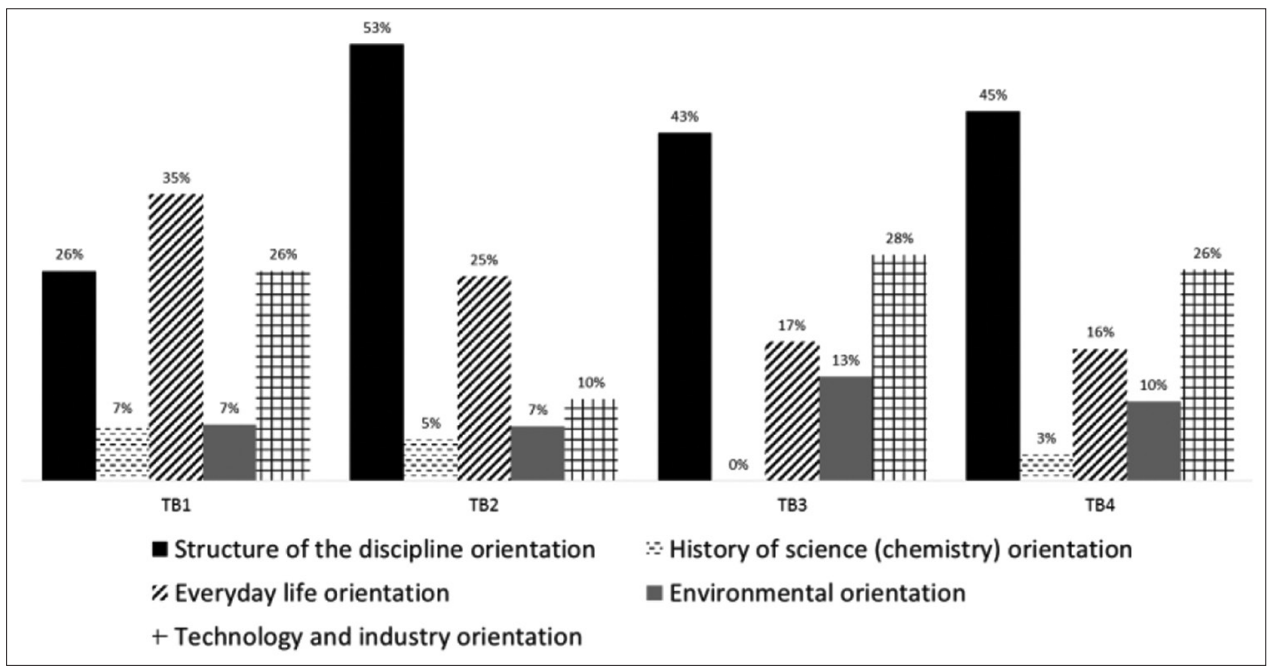

Figure 9: Distribution of the visual representations regarding curriculum orientation in four Brazilian textbooks (TB) 


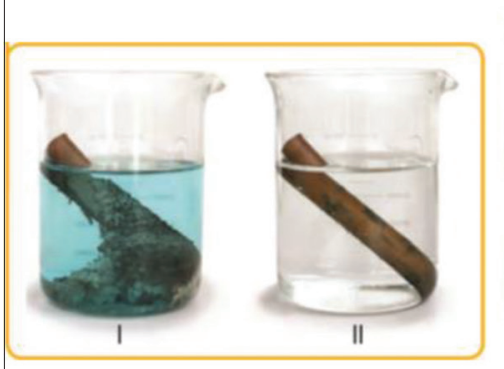

a

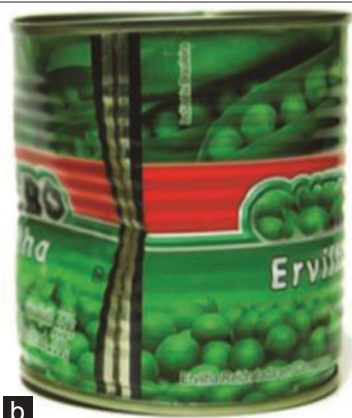

b

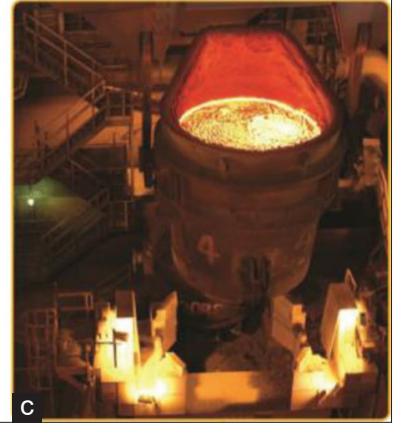

Figure 10: Examples of visual representations of (a) structure of the discipline, (b) everyday life orientation, and (c) industry and technology orientation. Santos and Mól (2013). Química Cidadã (2ed. Vol.3). São Paulo: AJS Ltda. Reproduced by permission of AJS Ltda, São Paulo, São Paulo

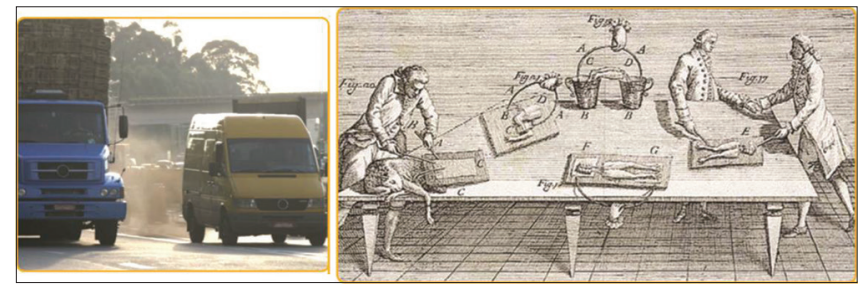

Figure 11: Examples of visual representations of (a) environmental orientation and (b) history of science orientation. Santos and Mól (2013). Química Cidadã (2ed. Vol.3). São Paulo: AJS Ltda. Reproduced by permission of AJS Ltda, São Paulo, São Paulo

result confirms the dominant function of most of the images, where the majority serves merely as decoration. The fact that roughly half of the images examined are related to daily facts and technology is corroborated by the predominance of representations at the macroscopic level. Figure 10 images $\mathrm{b}$ and $\mathrm{c}$ are examples of such figures, which show things in everyday life (b) or in the industry (c). Pictures focusing on environmental issues and the history of chemistry are less prevalent.

Figure 11 presents two examples: environmental (A) and history of chemistry (B).

It is important to emphasize that the images alone cannot reveal the curriculum orientation. This is a question of how they are embedded and used by the teachers. They provide, however, indications of how the content in question is suggested to become visually contextualized. Figure 11 provides two examples where one is near to everyday life of the students and environmental problems associated with it, whereas the other picture provides a historical sketch far away from today's life of the students. More in-depth analysis in the future might investigate how teachers use the images provided in textbooks.

\section{CONCLUSION}

Given the influence of textbooks and the importance of using representations in teaching chemistry (Devetak and Vogrinc, 2013), it is essential that the use of representations in the textbooks be well-planned. It is fundamental for teachers to review the textbooks critically concerning its visual representations of content, for the topic of redox reactions in particular, but also for other chemistry contents in general. Characterizing and reflecting the representations can help in understanding the content and facilitate the teaching of it. Chen et al. (2019) recently presented a similar comparison of representations of redox reactions in chemistry textbooks, but the Chen et al. study had a focus on Chinese educational contexts. The current study analyzed visual representations of redox reactions found in four different chemistry textbooks approved by educational authorities in Brazil. Textbooks are widely used as teaching material in Brazilian schools. The results show that the use of visual representations across the four textbooks is very similar to each other. Besides that, they reflect both the similar and different trends already identified in the literature. Although images appear throughout the examined textbooks, the number of disconnected illustrations without relevant links to the information given in the main text is quite considerable. It was found that only $17 \%$ of the representations were completely related to the text in question. More than $55 \%$ of the visual representations served a decorative function only.

In the same way, the literature reveals a prioritization among textbooks of two of the levels of representation: The macroscopic and the symbolic. While the redox reactions content covers many abstract concepts, illustrations at the submicroscopic level are much less frequent in Brazilian schoolbooks, representing $<2 \%$ of the total. The redox reactions concept should be represented in the textbooks more thoroughly using images at different representational levels. In this way, students might be better able to imagine the concept in the connection between the different levels. Representations combining two or more representational levels often are employed without adequately emphasizing or explaining the interconnectedness of the levels. Only $15 \%$ of the illustrations could be characterized as sufficiently linked to the text. It is difficult for students to understand what the image involves and what the aim of it is. Thus, textbook authors should be careful about linking any images to the text.

In general, the illustrations focus on a structure of the discipline approach but also providing everyday life and technology or industry references. Historical, environmental and socioscientific aspects remain rare. Different curriculum 
orientations offer alternative ways of approaching chemistry content. Everyday life and technology-industry orientations provide an excellent way for students to realize the importance of redox reactions and their pervasive applications in their own lives. Our results show that textbooks are concerned with contextualization and try to involve students with issues related to life and the environment in which they live.

In the same way as in the results pointed out by Mendonça et al. (2004), it was observed that the development of the concept of redox reactions in the textbook was unfavorable to the teaching and learning and could contribute to misconceptions in both students and chemistry teachers. In addition to the results obtained from the categories analyzes, it could be said that the textbooks presented a relationship between the intended chemistry curricula and certain characteristics of the country. Brazil still has a more technical education but some changes may be observed in the sense of more contextualized teaching. Since the textbooks are subject to the approval of a Government Program (the PNLD), their authors followed certain guidelines and included some aspects like technology and everyday life, but often disconnected with the text and content. This study points out that textbooks may be indicators of educational issues. For example, from the analysis of textbooks, it was possible to find indications whether or not a country prioritized context-based teaching.

The results of this study reveal much potential for improving the representation of redox reaction content in chemistry textbooks. Textbooks can be an excellent material for both students and teachers. However, improving students' deep understanding of redox reactions requires that textbooks use different representations and multilevel representations, which help the learners to move between different representational levels easily. This needs to be performed in a way to represent the submicroscopic level better. Explanations of the interconnectedness of and interrelatedness between the different levels need to be added and more tightly tied to the material presented in the main text. Another concern is more thorough coverage of the historical, environmental, and socioscientific orientation of science since such approaches can support and enrich the contexts covered in Brazilian chemistry textbooks, even if another curriculum focus for teaching redox reactions is chosen.

The results of this paper provide useful information to help chemistry teachers in choosing textbooks and supporting media. It will hopefully aid curriculum developers, textbook authors and teachers in their awareness of factors for improving chemistry textbooks concerning redox reactions. Reforming new textbooks can ensure that they include the three levels of visual representation in a way to help students move between different levels of representation. One limitation of this research is that it only focused on book chapters dealing specifically with redox reactions. Further research can elaborate on whether the findings described in this paper are also valid for other chemistry topics and how they are represented in chemistry textbooks. Although the example relates to chemistry, the same method can be used for any science textbook. It can also be expanded to compare how the same material is represented in textbooks from other countries. Moreover, further research could be done on how teachers use images from textbooks in their classrooms and how students interpret them.

\section{ACKNOWLEDGMENTS}

The authors are grateful to the financial support, Coordination for the Improvement of Higher Education Personnel (CAPES) and São Paulo Research Foundation (FAPESP), Grants \#2013/07937-8; \#2014/14356-4; \#2016/16354-4 and \#2016/08677.

\section{REFERENCES}

Adu-Gyamfi, K., Ampiah, J.G., \& AgyeI, D.D. (2018). Teachers' problems of teaching of oxidation-reduction reactions in high schools. European Journal of Education Studies, 5(5), 53-71.

Al-Balushi, S.M., \& Al-Harthy, I.S. (2015). Students' mind wandering in macroscopic and submicroscopic textual narrations and its relationship with their reading comprehension. Chemistry Education Research and Practice, 16, 680-688.

Antunes, M.T. (2013). Be Protagonist: Chemistry 2. $2^{\text {nd }}$ ed. Edições SM. Barke, H.D., Hazari, A., \& Yitbarek, S. (2009). Misconceptions in Chemistry. Berlin: Springer.

Barral, F.L., Fernández, E.G.R., \& Otero, J.R.G. (1992). Secondary students' interpretation of the process occurring in an electrochemical cell. Journal of Chemical Education, 69, 655-657.

Basheer, A., Hugerat, M., Kortam, N., \& Hofstein, A. (2017). The effectiveness of teachers' use of demonstrations for enhancing students' understanding of and attitudes to learning the oxidation-reduction concept. Eurasia Journal of Mathematics Science and Technology, 13, 555-570.

Becker, N., Stanford, C., Towns, M., \& Cole, R. (2015). Translating across macroscopic, submicroscopic, and symbolic levels: The role of instructor facilitation in an inquiry-oriented physical chemistry class. Chemistry Education Research and Practice, 16, 769-785.

Bizzo, N., Monteiro, P.H.N., Lucas, M.B., \& Bianco, A.A.G. (2012). Corrected science textbooks and snakebite casualties in Brazil: 19932007. Science Education International, 23(2), 286-292.

Brasil, \& Ministry of Education. (1999). National Curricular Parameters for High School. Brasil: Ministry of Education.

Brasil, \& Ministry of Education. (2009). National Textbook Program. Brasil: Ministry of Education.

Carney, R.N., \& Levin, J.R. (2002). Pictorial illustrations still improve students' learning from text. Educational Psychology Review, 14, 5-26.

Carvalho, G.S., \& Clément, P. (2007). Relationships between digestive, circulatory, and urinary systmes in portuguese primary textbooks. Science Education International, 18(1), 15-24.

Chen, X., Goes, L.F., Treagust, D., \& Eilks, I. (2019). An analysis of the visual representation of redox reactions in secondary chemistry textbooks from different Chinese communities. Education Sciences, 9(1), 1-16.

Cheng, M.M.W., \& Gilbert, J.K. (2014). Students' visualization of metallic bonding and the malleability of metals. International Journal of Science Education, 36, 1373-1407.

Cook, M.P. (2006). Visual representations in science education: The influence of prior knowledge and cognitive load theory on instructional design principles. Science Education, 90, 1073-1091.

De Jong, O., \& Treagust, D.F. (2002). The teaching and learning of electrochemistry. In: Gilbert, J.K., De Jong, O., Justi, R., Treagust, D.F., \& Van Driel, J.H., (Eds.), Chemical Education: Towards ResearchBased Practice. Berlin: Kluwer Academic Publishers. pp. 317-337.

De Jong, O., Acampo, J., \& Verdonk, A. (1995). Problems in teaching the topic of redox reactions: Actions and conceptions of chemistry teachers. Journal of Research in Science Teaching, 32, 1097-1110. 
De Jong, O., Blonder, R., \& Oversby, J. (2013). How to balance chemistry education between observing phenomena and thinking in models. In: Eilks, I., \& Hofstein, A., (Eds.), Teaching Chemistry-A Studybook. Rotterdam: Sense. pp. 97-126.

Devetak, I., \& Vogrinc, J. (2013). The criteria for evaluating the quality of the science textbooks. In: Khine, M.S., (Ed.), Critical Analysis of Science Textbooks: Evaluating Instructional Effectiveness. Berlin: Springer. pp. 3-15

Dimopoulos, K., Koulaidis, V., \& Sklaveniti, S. (2003). Towards an analysis of visual images in school science textbooks and press articles about science and technology. Research in Science Education, 33, 189-216.

Eilks, I. (2013). Teacher pathways through the particulate nature of matter in lower secondary school chemistry: Continuous switching between different models or a coherent conceptual structure? In: Tsaparlis, G., \& Sevian, H., (Eds.), Concepts of Matter in Science Education. Berlin: Springer. pp. 213-230.

Eilks, I. (2015). Science education and education for sustainable development-justifications, models, practices and perspectives. Eurasia Journal of Mathematics Science and Technology Education, 11(1), 149158.

Eilks, I., Moellering, J., \& Valanides, N. (2007). Seventh-grade students' understanding of chemical reactions: Reflections from an action research interview study. Eurasia Journal of Mathematics Science and Technology Education, 3(4), 271-286.

Eilks, I., Rauch, F., Ralle, B., \& Hofstein, A. (2013). How to Allocate the chemistry curriculum between science and society. In: Eilks, I., \& Hofstein, A., (Eds.), Teaching Chemistry-A Studybook. Rotterdam: Sense. pp. 1-36.

Eilks, I., Witteck, T., \& Pietzner, V. (2012). The role and potential dangers of visualisation when learning about submicroscopic explanations in chemistry education. Center for Educational Policy Studies Journal, 2, 125-145.

FNDE. (2017). About the National Textbook. Available from: http://www. fnde.gov.br/programas/programas-do-livro.

Fonseca, M.R.M. (2013). Chemistry 2. (1 $1^{\text {st }}$ ed.) Ática.

Gabel, D. (1999). Improving teaching and learning through chemistry education research: A look to the future. Journal of Chemical Education, $76,548-554$.

Garnett, P.J., \& Treagust, D.F. (1992a). Conceptual difficulties experienced by senior high school students of electrochemistry: Electric circuits and oxidationreduction equations. Journal of Research in Science Teaching, $29,121-142$

Garnett, P.J., \& Treagust, D.F. (1992b). Conceptual difficulties experienced by senior high school students of electrochemistry: Electrochemical (galvanic) and electrolytic cells. Journal of Research in Science Teaching, 29, 1079-1099.

Gibin, G.B., \& Ferreira, L.H. (2013). Students' evaluation about the use of images as auxiliary resource in teaching chemical concepts. New Chemistry at School, 35, 19-26.

Gibin, G.B., Kiill, K.B., \& Ferreira, L.H. (2009). Categorization of the images regarding the subject chemical equilibrium in the books approved by the PNLEM. Electronic Journal of Science Education, 8, 711-721.

Gilbert, J.K. (2006). On the nature of "context" in chemical education. International Journal of Science Education, 28, 957-976.

Gilbert, J.K., \& Treagust, D.F. (2009). Introduction: Macro, submicro and symbolic representations and the relationship between them: Key models in chemical education. In: Gilbert, J.K., \& Treagust, D.F., (Eds.), Multiple Representations in Chemical Education. Berlin: Springer. pp. $1-10$.

Gkitzia, V., Salta, K., \& Tzougraki, C. (2011). Development and application of suitable criteria for the evaluation of chemical representations in school textbooks. Chemistry Education Research and Practice, 12, 5-14.

Huddle, P.A., White, M.D., \& Rogers, F. (2000). Using a teaching model to correct known misconceptions in electrochemistry. Journal of Chemical Education, 77, 104-110.

Irby, S.M., Phu, A.L., Borda, E.J., Haskell, T.R., Steed, N., \& Meyer, Z. (2016). Use of a card sort task to assess students' ability to coordinate three levels of representation in chemistry. Chemistry Education Research and Practice, 17, 337-352.
Izquierdo, M., \& Gouvea, G. (2008). A proposal for textbooks analysis Rhetorical structures. Science Education International, 19(2), 209-218.

Johnstone, A.H. (1982). Macro and microchemistry. School Science Review, $64,377-379$.

Johnstone, A.H. (1991). Why is science difficult to learn? Things are seldom what they seem. Journal of Computer Assisted Learning, 7, 75-83.

Johnstone, A.H. (1993). The development of chemistry teaching: A changing response to changing demand. Journal of Chemical Education, 70, 701-705.

Johnstone, A.H. (2006). Chemical education research in Glasgow in perspective. Chemistry Education Research and Practice, 7, 49-63.

Johnstone, A.H. (2010). You can't get there from here. Journal of Chemical Education, 87, 22-29.

Kapici, H.Ö., \& Savasci-Açikalin, F. (2015). Examination of visuals about the particulate nature of matter in Turkish middle school science textbooks. Chemistry Education Research and Practice, 16, 518-536.

Khaddoor, R., Al-Amoush, S., \& Eilks, I. (2017). A comparative analysis of the intended curriculum and its presentation in $10^{\text {th }}$ grade chemistry textbooks from seven Arabic countries. Chemistry Education Research and Practice, 18, 375-385.

Lee, S.J. (2007). Exploring students' understanding concerning batteriestheories and practices. International Journal of Science Education, 29, 497-516.

Lee, V.R. (2010). Adaptations and continuities in the use and design of visual representations in US middle school science textbooks. International Journal of Science Education, 32, 1099-1126.

Llanos, V.C., \& Otero, M.R. (2018). Characteristics and changes in the mathematics textbooks for the secondary school in Argentina along 67 years. International Journal of Educational Research, 4, 98-105.

Mahaffy, P. (2004). The future shape of chemistry education. Chemistry Education Research and Practice, 5, 229-245.

Markic, S., Broggy, J., \& Childs, P. (2013). How to deal with linguistic issues in chemistry classes. In: Eilks, I., \& Hofstein, A., (Eds.), Teaching Chemistry-A Studybook. Rotterdam: Sense. pp. 127-152.

Mendonça, R.J., Campos, A.F., \& Jófili, Z.M.S. (2004). The oxidationreduction concept in high-school textbooks of organic chemistry. New Chemistry at School, 20, 45-48.

Mortimer, E.F., \& Machado, A.L. (2013). Chemistry 2: High School. $\left(2^{\text {nd }}\right.$ ed.) Scipione.

Niaz, M., \& Chacón, E. (2003). A conceptual change teaching strategy to facilitate high school students' understanding of electrochemistry.

Journal of Science Education and Technology, 12, 129-134. Nyachwaya,

J.M., \& Gillaspie, M. (2016). Features of representations in general chemistry textbooks: A peek through the lens of the cognitive load theory. Chemistry Education Research and Practice, 17, 58-71.

Nyachwaya, J.M., \& Wood, N.B. (2014). Evaluation of chemical representations in physical chemistry textbooks. Chemistry Education Research and Practice, 15, 720-728.

Österlund, L.L., \& Ekborg, M. (2009). Students' understanding of redox reactions in three situations. Nordic Studies in Science Education, 5, 115-127.

Österlund, L.L., Berg, A., \& Ekborg, M. (2010). Redox models in chemistry textbooks for the upper secondary school: Friend or foe? Chemistry Education Research and Practice, 11, 182-192.

Özkaya, A.R. (2002). Conceptual difficulties experienced by prospective teachers in electrochemistry: Half-cell potential, cell potential, and chemical and electrochemical equilibrium in galvanic cells. Journal of Chemical Education, 79, 735-738.

Perales, F.J., \& Jiménez, J.D.D. (2002). The illustrations in the teachinglearning of the sciences: Textbook analysis. Didactic Research, 20, 369386.

Pintó, R., \& Ametller, J. (2002). Students' difficulties in reading images. Comparing results from four national research groups. International Journal of Science Education, 24, 333-341.

Posada, J.M. (1997). Conceptions of high school students concerning the internal structure of metals and their electric conduction: Structure and evolution. Science Education, 81, 445-467.

Pozzer-Ardenghi, L., \& Roth, W.M. (2005). Making sense of photographs. Science Education, 89, 219-241

Ringnes, V. (1995). Oxidation-reduction: Learning difficulties and choice of 
redox models. School Science Review, 77, 74-78.

Roseman, J.E., Stern, L., \& Koppal, M. (2010). A method for analyzing the coherence of high school biology textbooks. Journal of Research in Science Teaching, 47, 47-70.

Sanger, M.J., \& Greenbowe, T.J. (1997a). Common student misconceptions in electrochemistry: Galvanic, electrolytic, and concentration cells. Journal of Research in Science Teaching, 34, 377-398.

Sanger, M.J., \& Greenbowe, T.J. (1997b). Students' misconceptions in electrochemistry regarding current flow in electrolyte solutions and the salt bridge. Journal of Chemical Education, 74, 819-823.

Sanger, M.J., \& Greenbowe, T.J. (1999). An analysis of college chemistry textbooks as sources of misconceptions and errors in electrochemistry. Journal of Chemical Education, 76, 853-860.

Sanger, M.J., \& Greenbowe, T.J. (2000). Addressing student misconceptions concerning electron flow in aqueous solutions with instruction including computer animations and conceptual change strategies. International Journal of Science Education, 22, 521-537.

Santos, W.L., \& Mól, G.S. (2013). Citizen Chemistry 3. ( $2^{\text {nd }}$ ed.) AJS LTDA.

Schmidt, H.J., Marohn, A., \& Harrison, A.G. (2007). Factors that prevent learning in electrochemistry. Journal of Research in Science

Teaching, 44, 258-283.

Sesen, B.A., \& Tarhan, L. (2013). Inquiry-based laboratory activities

in electrochemistry: High school students' achievements and attitudes. Research in Science Education, 43, 413-435.
Sjöström, J., \& Talanquer, V. (2014). Humanizing chemistry education: From simple contextualization to multifaceted problematization. Journal of Chemical Education, 91, 1125-1131.

Slough, S.W., McTigue, E.M., Kim, S., \& Jennings, S.K. (2010). Science textbooks' use of graphical representation: A descriptive analysis of four sixth grade science texts. Reading Psychology, 31, 301-325.

Souza, K.A.F., \& Porto, P.A. (2012). Chemistry and chemical education through text and image: analysis of twentieth century textbooks used in Brazilian context. Science Education, 21, 705-727.

Stern, L., \& Roseman, J.E. (2004). Can middle-school science textbooks help students learn important ideas? Findings from project 2061's curriculum evaluation study: Life science. Journal of Research in Science Teaching, $41,538-568$

Tan, K.C.D., Goh, N.K., Chia, L.S., \& Treagust, D.F. (2009). Linking the macroscopic, submicroscopic and symbolic levels: The case of inorganic qualitative analysis. In: Gilbert, J.K., \& Treagust, D. (Eds.), Multiple Representations in Chemical Education. (pp. 137-150). Springer.

Treagust, D., Chittleborough, G., \& Mamiala, T. (2003). The role of submicroscopic and symbolic representations in chemical explanations. International Journal of Science Education, 25, 1353-1368.

Valanides, N., Nicolaidou, A., \& Eilks, I. (2003). Twelfth grade students' understanding of oxidation and combustion: Using action research to improve teachers' practical knowledge and teaching practice. Research in Science and Technological Education, 21, 159-175. 